\title{
The state and my happiness: Youth mental health, citizenship education and discursive contestations in contemporary Indonesia
}

\author{
Teguh Wijaya Mulya ${ }^{1}$ (1) | Francesca Salvi $^{2}$ (1) | Paul Gorczynski ${ }^{3}$ (1) | \\ Tanya Wells Brown ${ }^{4}$ (1)
}

${ }^{1}$ Faculty of Psychology, University of Surabaya, Surabaya, Indonesia

${ }^{2}$ School of Education and Sociology, Faculty of Humanities and Social Sciences, University of Portsmouth, Portsmouth, UK

${ }^{3}$ School of Sport Health and Exercise Science, Faculty of Science and Health, University of Portsmouth, Portsmouth, UK ${ }^{4}$ London School of Hygiene and Tropical Medicine, London, UK

\section{Correspondence}

Teguh Wijaya Mulya, Faculty of Psychology, University of Surabaya,

Surabaya, Indonesia.

Email: teguh@staff.ubaya.ac.id

\section{Funding information}

This work was supported by the University of Portsmouth through a Themes Research and Innovation Fund 2019.

\begin{abstract}
Complementing studies on youth mental health that were mainly depoliticised, this article offers a discursive examination of youth mental health in an Indonesian educational context. We argue that subject positions enabled by the discourse of mental health were at odds with dominant constructions of an ideal Indonesian citizen. Drawing upon qualitative data from 22 teachers and 20 students in a junior high school in Indonesia and analyses of educational policies and textbooks, we identified three discourses underpinning the ideal(ised) constructions of young Indonesian citizen, namely, neoliberalism, (masculine) patriotism and (religious) moralism and discussed how these inhibited youth mental health.
\end{abstract}

\section{K E Y W O R D S}

citizenship education, discourse analysis, Indonesia, youth mental health

\section{INTRODUCTION}

Studies on youth mental health from mainstream psychological, psychiatric and public health traditions frame mental health within a depoliticised field. From these perspectives, mental health is constituted as value-free, individual(-ised) and biomedical(-ised). This article departs from such constructions and offers a discursive examination of youth mental health in an Indonesian educational context in order to highlight its political underpinnings. Our main argument is that subject positions 
enabled by the dominant discourse of mental health might be at odds with the historically powerful constructions of an ideal young Indonesian citizen. Consequently, the teachings of mental health promotion have struggled to find a way among contemporary Indonesian educational practices. The implications of this analysis offer some insights in relation to how youth mental health promotion could more effectively navigate and negotiate these discursive terrains.

This research contributes to academic knowledge at the intersection of mental health and citizenship studies, which is hitherto understudied in both international and Indonesian contexts. The limited number of existing studies falls mainly into three areas. Before we discuss these three areas, it is important to note that studies in this intersecting field defined mental health differently and examined different symptoms and disorders, but they primarily drew attention to the homogenous experience of stigmatisation among people with mental illness. In the current article, we refer to mental health as 'a state of well-being in which the individual realizes his or her own abilities, can cope with the normal stresses of life, can work productively and fruitfully, and is able to make a contribution to his or her community' (WHO, 2018, March 30, para. 2).

Firstly, a common link between mental health and citizenship studies is the notion of human rights. Prior's (2007) research in the European context, for example, identified how stigma attached to individuals with mental illness prevented them from accessing citizen rights such as employment, housing and family life. Correspondingly, Kelly (2009) advocated for the importance of addressing mental health using culturally sensitive approaches in order to respect various ethnic groups' rights as a citizen. In Asian contexts, Crabtree and Chong (2000) and Irmansyah et al. (2009) made a similar call for the government to protect the rights of people with mental illness in Malaysia and Indonesia, respectively. To the best of our knowledge, the study of Irmansyah et al. is the only Indonesian study linking mental health and citizenship.

The second area of research in this field considers how to re-integrate people with mental illness into their communities. In other words, it looks at enabling individuals previously diagnosed with mental health conditions to regain access to their citizenship rights fully or in part. These studies problematised the separated spheres of mental health care and citizenship practices, including how mental health services are different/separated from public health systems and the relationship between an individual's mental health and life in the community (Atterbury \& Rowe, 2017; Pelletier et al., 2009). Some researchers have documented creative citizenship-oriented mental health projects, such as McCabe et al. (2007) who reported on the participation of people with mental illness in public life via art projects. Pols' (2016) proposal of 'relational citizenship' refers to instances where people with mental illness are creating different forms of new social spaces and creative citizenry, from organising recreational trips with fellow outpatients to developing community engagement through musical performances about the hardship they have overcome.

The third area investigates mental health policies, practices and services within the context of neoliberal citizenship — a form of citizenship where free market logics are the dominant organising principle. Morrow (2004), for example, identified the tension between cost-efficiency policies and mental health services in Canada. Woolford and Nelund (2013) examined the infiltration of neoliberal ideologies into the intricacies of social service agencies, from embracing business-like and individualising model of service to encouraging service users to adopt neoliberal subjectivity (e.g., active, prudent, autonomous, responsible and entrepreneurial) before they are considered worthy of care. The problem here is that those unable or unwilling to conform to these neoliberal ideals for any sociocultural-ideological reason remain excluded, thereby losing their citizenship rights. In the same vein, Harris (2004) demanded university students who experienced mental illness to be constituted through a citizenship rather than consumer paradigm. This means to recognise them as citizens with a set of educational rights, instead of customers seeking satisfaction from being transformed into successful 
future workers. Outside of the West, Ecks (2005) criticised antidepressants marketing in India for bringing individuals with mental illness back into (middle-class consumerist) society, or what he called 'pharmaceutical citizenship'. Sung (2010) investigated the ways North Korean settlers in South Korea have been psychiatrically diagnosed with 'learned passivity' and 'incompetent personhood', programmed by the communist regime, so that they are less autonomous and responsible for social and economic life, not possessing self-management skills such as financial prudence-which is at the very heart of South Korean neoliberal citizenship. In linking mental health and citizenship, scholars in these three areas have mainly studied people who were diagnosed with mental illness, not the broader members of the public, such as young people in educational settings. Broadening the focus, looking at the construction of identities within an educational setting allows us to develop a new angle over the meaning and implications of mental health. We add to the existing knowledge in this field by researching youth mental health and citizenship education in an Indonesian context.

This paper revolves around two main research questions: What are the dominant discourses on ideal(ised) forms of citizen circulating within Indonesian educational practices? How is youth mental health positioned within these discourses? We explored these questions with 22 teachers and 20 students in a junior high school in Surabaya, Indonesia, and by analysing them against Indonesian educational policies, official student textbooks, official teacher guidebooks and media reports. Our analysis is not representative nor generalisable for all Indonesian youth in any educational setting, but we expect it to have a degree of resonance with other similar contexts or offer a sense of connectedness for wider Indonesian audience and relevant readers.

\section{A BRIEF INTRODUCTION TO CITIZENSHIP AND MENTAL HEALTH IN THE INDONESIAN EDUCATION SYSTEM}

As the home of the world's largest Muslim population, Indonesia's official state ideology documents position the country as — not an Islamic nor secular state, but — a religious, Pancasila-based country (Intan, 2006). Pancasila (translates as 'five principles') is the official state ideology established during Indonesia's independence in 1945, which consists of five principles, namely, (1) belief in one supreme God, (2) humanity, (3) unity, (4) democracy and (5) social justice. Holding together an extraordinary diversity of cultures, languages, ethnicities and religions, Pancasila (and its popular slogans such as 'unity in diversity') provides an ideological framework for a democratic, multicultural and tolerant citizenship (Parker \& Hoon, 2013). Nevertheless, the first two leadership regimes, Soekarno (1945-1965) and Soeharto (1966-1998), have appropriated and used Pancasila as a platform to maintain their political power in ways that are not necessarily either multicultural or tolerant (Uebadillah, 2018). While the history of Indonesian citizenship education can be traced back to the pre-independence era, Soeharto's citizenship vision and programmes had the most influential impact on contemporary Indonesian citizenship education, as the post-war Soekarno regime was too politically unstable to achieve a successful citizenship educational programme.

Soeharto's vision of citizenship was centred on anti-communism and economic developmentalism (Hoon, 2013). Rising to power during Indonesian political turbulence in the 1960s by scapegoating the Indonesian Communist Party, Soeharto promised order and stability for Indonesia's economic development. Good citizens were then defined as loyal to Pancasila and obedient to the Soeharto regime through a 'family principle' (azas kekeluargaan) that identified the state/Soeharto as the father and every citizen a child. It follows that Indonesians should obey the wise state and sacrifice their individual interests for the sake of family/state harmony and economic success (Robinson, 2014). These citizenship ideals were enacted through Pancasila citizenship education and additional compulsory 
training for all secondary and tertiary students called Penataran P4. Imbued with a strong sense of nationalism, patriotism and militarism, these programmes expected students to comply with a single interpretation of Pancasila and wholeheartedly support the regime with a sense of duty (Uebadillah, 2018). The teaching method was traditionally authoritarian: the teachers indoctrinated, while the students performed rote memorisation.

After the fall of Soeharto in 1998, there have been efforts to revitalise citizenship education, particularly by the Indonesian Centre for Civic Education in the Jakarta State Islamic Institute. Ideologically, citizenship education is now oriented towards democracy, human rights and civil society; the learning approach is directed to be a participatory one, and classrooms are expected to be a democratic space (Jackson \& Bahrissalim, 2007). Today, traces of Soeharto's citizenship ideals still find their ways into the curriculum and educational practices. Transforming decades of militaristic teaching and learning culture into a democratic one may need a significant amount of time, effort and persistence.

Besides commencing Indonesia's democratic reformation, the fall of Soeharto during the monetary crisis in 1997-1998 also marked the expanding of neoliberal reforms in Indonesia, including those affecting the education sectors (Burford \& Wijaya Mulya, 2019). As a part of the International Monetary Fund's rescue package, Indonesia complied with free-market-oriented recommendations, including the loosening of rules for foreign investments, corporatisation of public governance and privatisation of state enterprises. In education, neoliberalism manifested in the decentralisation of educational management and finances, vocationalisation of secondary education, internationalisation and marketisation of specifically selected schools and the strengthening of audit culture through accreditation mechanisms (Mappiasse, 2014). To ensure compliance, the performances of students, teachers and schools have been increasingly measured, quantified and standardised through a meticulous system of accreditation. The high-stake, standardised National Examinations (Ujian Nasional) in Years 6, 9 and 12, for example, have put immense pressures on students, teachers and schools to achieve the minimum requirements of performance. In education policies, such demands were often justified using neoliberal rhetoric, like for the sake of Indonesian human resource competitiveness in the global economy (Wijaya Mulya, 2016).

Within such pressures to perform, mental health is hardly a part of the current Indonesian curriculum (e.g., in the official Junior High School counselling guidebook, 2016), one that is framed and subsumed under nationalist or neoliberal purposes. Health and Physical Education, for example, overwhelmingly focuses on physical health and physical and psychological development, without any mention of mental health. School counsellor guidebooks are mainly underpinned by developmental psychological approaches confirming normative developmental norms. For instance, among 10 main developmental tasks stated in the Junior High School Counsellor guidebook (2016, p. 13), almost none are about students' mental health, but rather, about—among others—being religious, behaving in a socially acceptable way, confirming gender roles and preparing for a future career. Compliance to these developmental norms is positioned as the ideals for Indonesian youth, encouraging them to pursue economic success, social integration and societal stability and not prioritising their personal happiness nor meaningful personhood beyond the dominant social norms. It is against this backdrop of contemporary Indonesia's neoliberal education, patriotic citizenship and democratisation that the current study took place.

\section{METHODOLOGY}

This article is a part of a mixed-method study exploring youth mental health and citizenship in Indonesia; the current article reports on findings from the qualitative element. We began by examining 
relevant policy and curriculum documents, including the Education Law (2003), official school counsellor guidebook, Citizenship Education student textbooks and teacher guidebooks. These documents illustrate contemporary Indonesia's politico-educational-discursive contestations in this specific intersecting field of mental health and citizenship education, for example, tensions between nationbuilding agenda, neoliberalisation of education and youth's mental health. To better understand how policies and the curriculum are enacted in everyday educational practices, we conducted three focused group discussions (FGDs) with students (aged 11-15 years) and a workshop for teachers in a junior high school in Surabaya, Indonesia. The school is a long standing private school, not affiliated with any religion (meaning, they accept students from any religion and provide religious education classes according to each student's religion), and located in a middle-low-income area in the northern part of Surabaya, where the majority of the students reside. Most of the students' parents are employees or small business owners.

The first author reached out to the school counsellor, who acted as gate-keeper in facilitating the research, including introducing the study to the school principal and the pupils, who were then invited to participate. Those expressing interests were given an information sheet and forms to collect parental consent. The process led to recruiting 20 students (aged 11-15), who participated in three FGDs in January 2020 - 11 female, nine male; nine in Year 7, six in Year 8 and five in Year 9. The audio-recorded FGDs were led by the first author and conducted in his and the students' first language, Bahasa Indonesia. The questions discussed were around aspects that make them happy/ unhappy, ways of dealing with unhappiness, those they may reach out to when having problems and characteristics of a good young citizen. To stimulate openness and a relaxed atmosphere, participants also engaged in a Jenga-like game with questions inscribed on the blocks. Participation was rewarded by offering all a USB stick (approx. USD3.5) as a thank you gesture. All participant names in this article are pseudonyms.

In the following week, we conducted a 3-h workshop with 22 teachers, around the topic of youth mental health. We began the workshop by discussing their initial understanding of mental health in groups and also their views on the characteristics of youth with good mental health and good citizens. Our aim was to identify how teachers defined 'good' citizenship in young people and what responsibilities the curriculum gave them to facilitate or strengthen it. The groups each had the opportunity to present their findings, and the sessions notes have been analysed and incorporated as qualitative data. All workshop participants read a participant information sheet, agreed and signed a consent form.

The data from the workshop and FGD transcripts were analysed together with the aforementioned policy and curriculum documents using a Foucauldian discourse analysis methodology (Willig, 2013). We first read the data twice to familiarise ourselves with the data. Then, we searched, identified and named possible competing discourses surrounding Indonesian youth mental health and citizenship. The data presented in this article serve as a series of illustrations for our analytical arguments, not as an objective, neutral and representative framework. Instead of psychometric accuracy and generalisability, the credibility of our analysis is predicated upon a sense of resonance with a wider Indonesian audience and the degree of insightfulness it offers for the advancement of knowledge in the field of mental health and citizenship.

\section{FINDINGS}

We identified at least three dominant discourses underpinning the ideal(ised) constructions of a young Indonesian citizen, which—we argue-may contradict ideas and practices offered by the discourse of 
mental health. They are the discourse of neoliberalism, (masculine) patriotism and (religious) moralism. Each of these will be discussed below.

\section{'Studying makes me unhappy!': Neoliberal citizenship and youth mental health}

The first set of interconnected themes we identified in the data from students, teachers, textbooks and policy documents are ideas around being competitive, excelling, performing well in a condition of high school work demand and taking responsibility for one's own future in the labour market. In this subsection, we argue that these themes exemplify a discourse of neoliberalism in education and might have competed with the discourse of youth mental health. Defined as 'the agenda of economic and social transformation under the sign of the free market' (Connell, 2013, p. 100), neoliberalism constitutes ideal citizens as active and responsible economic actors, displaying characteristics such as prudent, competitive, ambitious, hardworking, independent, self-managed and entrepreneurial. Education is then positioned as the process of nurturing, disciplining and developing students to be these neoliberal subjects.

Our analysis of textbooks and policy documents evidenced this positioning of students as neoliberal subjects being prepared to compete in the market through education. In the Introduction of the official Junior High School Counselling guidebook (2016, p. ii), for instance, the Directorate General of Teachers and Educational Workforce emphasises 'the importance of the educational unit in developing students as human resource for Indonesia's future ... With teachers' wholehearted dedication, students can compete and achieve brilliantly in the global arena'. As neoliberal reforms gradually unfolded in the Indonesian education system (Mappiasse, 2014), these neoliberal terms, language and logics increasingly infiltrated Indonesian educational policies and everyday practices. Similar neoliberal terms of competitiveness, achievement and humans as resources were also evident among teachers in our workshop when discussing characteristics of 'good young citizens', such as 'high motivation in studying', 'joining external competitions' and 'healthy competitive environment at school'. Here, an emphasis on academic performance is of paramount importance, and creative endeavours are oriented towards winning competitions, to the extent that students during FGDs characterised the learning at school as 'burdening', 'too many assignments', 'too demanding' and 'not enjoyable'. Consequently, as previous international studies have evidenced (Giota \& Gustafsson, 2017; Högberg et al., 2021), a condition of high academic demands inevitably resulted in students' poor mental health, or in our FGD participants' word, 'burdened' (Oki, Year 8) and 'stressed out' (Roni, Year 8).

Researcher: What makes you unhappy in life?

Dini: Studying!

Victor: Yeah, the subjects (at school).

Oki: I feel burdened.

(FGD with Year 8 students).

Although speaking about studying in negative tones, students in the FGDs were also quick to add that it was all for their own sake- exhibiting another mechanism of neoliberal subjectivation, namely, responsibilisation (Torrance, 2017). Roni and Dini (Year 8), for example, complained about their parents 
sending them to additional piano and Mandarin after-school lessons, but they immediately explained the rationale for the after school work: 'I want it myself too, because I want to get a scholarship to go study in China, or work as a translator. So I must learn hard, however tired I am'. This quote displays how students internalised the need for extra demands on their time as a form of responsibility for their own future in the labour market. This is in line with the mechanisms of modern power in disciplining society (Foucault, 1972), where subjects are not simply forced to comply, but they are continuously (re)produced as (neoliberal) subjects who are willing to comply through mechanisms of normalisation, evaluation and responsibilisation. Constituting their subjectivity through such neoliberal discourse, 'getting good grades' frequently came up during the FGDs as something that makes them happy as youth, and 'representing the school in academic competitions' (Jessica, Year 9) is a proud achievement. Responsibilised for their own success/failure, expectations of self-blaming were also common when talking about those who failed academically: 'I think they are just lazy' (Jessica, Year 9).

Further, our analysis identified how the neoliberalisation of education - in addition to the students'also affected teachers' mental health, as similar logics and expectations of performance and responsibilisation apply to them as well. When organising the workshop, we were told by the school counsellor that those days the teachers were often working overtime because they prepared accreditation documents (filled out forms, wrote detailed lesson plans, put together evidence of learning, collected certificates for professional development proofs, etc.), and the pressures were intense as the school's reputation was at stake. Within Indonesia's school accreditation system, demands to perform as a teacher and a school are added with the burden to document and demonstrate performance through meticulous audit mechanisms. As the school counsellor described, Indonesian school accreditation procedure generally requires a bulk of 'nonsensical documentations of everything we did'. In turn, this pressure to perform affected the teachers' workload and their (avail-)ability to pay attention to students' mental health. During the workshop, teachers expressed a genuine sense of care for students' mental health. For example, they appeared to know which students need support, what those students' background conditions are and how they preferred to be helped (first author-workshop notes). However, teachers considered it 'unrealistic to spend time helping students with their problems while we ourselves are burdened with high workload. What about our own mental health?' (quoted from workshop notes)

While the enactment of neoliberal educational reforms might be slightly different across the globe, recent studies have reported how teachers all over the world from Australia (Willis et al., 2019), Norway (Ekornes, 2017), to China (Yang et al., 2019) were similarly struggling with students' and their own mental health in the face of such reforms. As these studies and our findings demonstrated, education for neoliberal citizenship has given little room for a discourse of mental health, as it prioritises performance and results over happiness and processes of growth.

\section{Tough and disciplined citizens: (Masculine) Patriotism and youth mental health}

Citizens must love and be willing to sacrifice for the nation and country. Someone with a sense of Indonesian nationhood would feel proud as an Indonesian citizen. Such pride can be felt when you participate in flag ceremonies at school. You see the flag gloriously rise in your schoolyard; also, the same feeling of pride when seeing our flag in international sports competitions.

(Year 7 Student Citizenship Education Textbook, 2017, p. 17) 
The second dominant discourse we identified in our data analysis is (masculine) patriotism, in which the ideal(ised) young citizens are constructed as dedicated to the country, having a sense of pride in being an Indonesian, ready to fight and sacrifice everything for the country and contributing to the nation through individual achievements. Through the legacy of Soeharto's azas kekeluargaan (family principles), this sense of patriotism applies in and expands to the contexts of family and school as well. We argue that this discourse is imbued with traditionally masculine characters, such as tough, hard and strongwilled (Nilan, 2009) and is widely circulating in the current Citizen Education curriculum and practices. Consequently, a (more traditionally feminine) idea of taking care of oneself, including one's mental health, might struggle to compete.

As the epigraph of this subsection demonstrates, official Citizenship Education textbooks (e.g., Year 7, 2017; Year 8, 2017; Year 9, 2017)—while purportedly introducing democracy, human rights and civil society - are still conveying strong messages of patriotic nationhood. Here, citizens' obligations to the country are prioritised over the country's obligation to protect citizenship rights. For example, the notion of bela negara (defending the country) - a central point in the learning of Indonesian citizenship-is widely spread throughout the textbook. Exemplification and romanticisation of preindependence fights against Dutch and Japanese colonisers represent the militaristic overtone of bela negara as a citizenship practice: 'Evidence of love to the country can be seen in the whole Indonesian people's sacrifice, both body and soul, to attain and defend our independence from the colonisers' (Year 7 textbook, 2017, p. 17). Foregrounding the fallen heroes, Citizenship Education calls the students to 'willingly sacrifice, that is, placing the country's interests over personal interests' (Year 7 Student Citizenship Education Textbook, 2017, p. 22). In contrast, textbooks were mainly silent on citizenship rights and how the country should protect these rights; when present, these were in the form of normative mentions (e.g., 'The law protects people's rights ... no citizens are treated differently before the law', Year 7, 2017, p. 50) without any real examples, elaborate discussions or emphases on defending one's rights. Incidents of state inaction on violations of minority rights, for instance, were not included in these textbooks. By emphasising patriotism, Citizenship Education teaches more about the people submitting themselves to the country, and less about the country's responsibilities to the people's rights, let alone their mental health.

In educational practices, the data in the current study showed that nationalist patriotism manifested in a sense of obligation, discipline and dedication imposed upon the students, including obligations to study, to obey school rules and the teachers, to dedicate their time and energy to their family, the school, and the nation and to attain achievements that make them proud. 'Coming to school on time' and 'submitting assignments on time', for example, were put as indicators of students' sense of nationalism in the Year 7 Citizenship Education textbook (2017, pp. 27-28). Further, the Year 9 Citizenship Education textbook (2017, p. 144) exemplified Indonesian students 'winning international Physics competition' when discussing nationalism in educational contexts. In a similar vein, during our workshop the teachers attached characteristics such as 'strong-willed', 'disciplined', 'tough', 'obeying school rules' and 'dedicated to submit homework on time' to the idea of a 'good young citizens'. During the FGDs, the students displayed an internalisation of these impositions, or to be precise, drew upon such discourses in the constitution of their subjectivity. Finding happiness in their dedication to authorities, Andi (Year 9) and Jessica (Year 9) responded with 'making my parents happy' and 'returning my parents' favour' respectively when asked about things that make them happy. School-related achievements were then came up when we asked what would make their parents happy, and to be 'diligent' and 'disciplined' are the ways, they see, towards such achievements. Through a discourse of patriotism, an ideal(ised) young Indonesian citizen is constituted as disciplined and fully dedicated to the family, the school and the country; their personal happiness or mental health might have to be put aside. 
The recent high-profile debate around the elimination of National Examination (Ujian Nasional) illustrates well the contestation between discourses of patriotism and mental health in the Indonesian educational context. In December 2019, the new Minister of Education, Nadiem Makarim, eliminated the high-stake national examination, which had existed for more than four decades. The reasons given by the Minister were that the national exam narrowly focused on cognitive aspects of education and has become a 'stressful burden' for students, parents and teachers (Uly, 2019, December 11, para. 3). Debating this topic, a top national journalist, Najwa Shihab (2019, December 18), invited some high school students to her popular talk show and interviewed them. Welcoming the elimination, they described the pressures, struggles and sacrifices, like halting any personal activity, hobbies and creative pursuits to focus on extracurricular tuitions a year before the exam-which in a way affected their mental health. In contrast, Jusuf Kalla, the former vice-president, criticised the elimination of the national exam as 'making the future generation meek' (Yuwono, 2019, December 13, para. 3). In Indonesia, the national exam has been commonly labelled as momok (a scary ghost) because its high-stake nature had infamously failed students from completing their education (e.g., Bona, 2015, January 5). Facing this ultimate educational challenge was analogous to facing a 'scary ghost', requiring bravery, fighting spirit and toughness. The new Minister refuted the critique and added that the new form of learning evaluation, replacing the national exam, will be 'more challenging' because it will be more substantive, in line with the requirements of the Programme for International Student Assessment. Rather than accepting 'meekness' and mental health as an important quality of future generation, the minister drew upon the same (traditionally masculine) discourse of toughness by positioning the new form of examination as 'more challenging'. This debate substantiates the tension between the notion of toughpatriotic-masculine young citizens, who are up for any demands imposed upon them, and those who are more internally focused and able to take care of their own selves. This latter view, which fits better with a discourse of mental health, is traditionally framed as feminine. Unsurprisingly, previous international studies showed that school stress in the last decades has increased more significantly among female students (e.gGiota \& Gustafsson, 2017; Högberg et al., 2020) whose ways of being might not match the demands of traditionally masculine discourses underpinning the schooling systems.

Moreover, nationalist patriotic discourses also manifested in teaching and assessment methods, in ways which might have hindered students from seeking help from teachers in response to mental health issues. The Year 8 Citizenship Education teacher guidebook, for example, recommends various teaching strategies to enhance students' sense of nationalism (2017, p. 18). These include (1) 'conditioning' where students are trained through assignments and behaviour monitoring to conform to the citizenship ideals, (2) 'teacher's role model', where teachers and school management provide exemplary citizenship behaviours, and (3) 'environmental arrangement' in which national symbols like flags, garuda bird and the president's and vice-president's photos are put up on the classroom walls. These methods were confirmed by the teachers in the workshop, as they explained ways of cultivating good citizenship, including 'serving as one of the officers in the flag ceremony' and 'singing the national anthem before the lesson start'. These citizenship educational strategies implied externally imposed changes to students' behaviours, rather than attending to students' ways of thinking, let alone their feelings. Simultaneously, these strategies position teachers as the imposing authority, while students as the powerless who must comply rather than engaging in two-way dialogues. Even worse, the teacher guidebook states that one of the main learning assessments in Citizenship Education is 'teacher's observation [upon the students' citizenship behaviours] in and out of the classroom' (p. 23). This is a key element, as it puts students under continuous panoptic behavioural surveillance with their citizenship education grade at stake. As Foucault (1979) noted, the illusion of being watched at all times is a crucial mechanism of modern power in disciplining individuals, which continuously (re) produces them into obediently docile subjects despite not being actually watched. Considering this 
discursive positioning of teachers and students, it was not surprising that during the FGDs students did not mention seeking help from teachers when asked about their coping strategies, but instead, 'keep everything inside', 'try to forget', 'listen to music', 'watch motivational Youtube videos' and 'find something else to do'. Having personal problems and needing help might not match the characters of ideal(ised) young citizens who are tough and ready to fight for the country, and opening up one's personal struggles and feelings to the rule enforcers/evaluators might become unthinkable.

\section{Obedient and pious citizens: (Religious) Moralism and youth mental health}

The final key discourse we consider here is one of (religious) moralism, in which the ideal(ised) young citizen is defined as morally obedient, piously religious and respectful of hierarchical social relationship. We argue that such discourse and its manifestations in educational (and family) contexts do not only contradict ideas espoused by the discourse of mental health like respect for personhood and individual freedom but also perpetuate forms of paternalistic relationship between youth and adults, which can be detrimental to youth mental health.

Our analysis of Indonesian Citizenship Education textbooks identified that moralistic terms, topics and messages such as obedience, respecting social norms, maintenance of moral order and the use of punishment were dominant and widespread throughout these textbooks. For instance, the Year 9 Citizenship Education textbook (2017, p. 52) explains about the law emphasising obedience: 'People must obey the law because the nature of the law is regulatory and binding. Law can force someone to obey the rules in society and those disobeying the law may be punished'. While there are some explanations in the books about why a society needs the law and social norms, or why it is important to abide by the law (Year 9 Citizenship Education textbook, 2017, pp. 50-51), there is no critical discussion of the contested nature of the law, social norms and morality. This implies that there is only one way to be a good citizen, that is, to unilaterally and uncritically obey existing norms. In Year 8, the Citizenship Education textbook (2017) asks students to work on the topic of 'Habituating Pancasila Values', with 'obeying parents' and 'obeying school rules' (p. 18) provided as exemplary answers. Along the same lines, the Year 7 textbook (2017, pp. 51-52) details what type of punishment may be enacted in response to failure to obey norms. This also includes the various forms and degrees of punishment in Indonesian justice system (including capital sentence), justifications for punishments and the wide scope of behaviours punishable by the law. These sections contain an element of scaremongering, which is reminiscent of Soeharto's era: to be morally and unquestioningly obedient to the law and authorities is perpetuated as the main trait of a good citizen.

What is relatively new, or at least much more pronounced in educational policies and textbooks, in comparison to Soeharto's era, is that this discourse of moralism is now frequently articulated within religious language. For instance, the first purpose of national education in the constitution (Education Law, 2003) is to develop students to be religious and pious (beriman dan bertaqwa), with the understanding of taqwa/pious as obeying religious rules and staying away from all that God has forbidden (Bhatti et al., 2015). The first paragraph in the first chapter in Years 7-9 Citizenship Education textbooks congratulates students on successfully entering the new academic year stating that they 'should thank God for this blessing'. Such presumed gratitude 'should be manifested in high learning motivation' (p. 1) and 'in observing religious obligations'. Both gratitude and religious observance are then to become learning self-assessment criteria (Year 7 Citizenship Education textbook, 2017, p. 27), in which students were asked to rate themselves against those criteria at the end of some chapters in the textbook. 
Moreover, to morally watch and remind other students' religious observance is an exemplary evidence of performing citizenship behaviours further to the guidance offered in teacher guidebooks (e.g., Year 8 Citizenship Education guidebook, 2017, p. 25). Teachers participating in this study reproduced similar notions of moralistic gesture when describing good young citizens. For example, when presenting the result of their group discussion, teachers in a group claimed that a form of good behaviour would entail being 'strict towards friends who violate the school's rules', such as reprimanding and reporting to school authorities. In fact, peer evaluation of obedience and religiosity is formally included in Citizenship Education learning assessment (Year 7 Citizenship Education textbook, 2017, p. 78). In addition to the teachers' panoptic evaluation (in the previous subsection), actively surveilling oneself and each other's moral obedience and religious ritualism is the way of being encouraged in Indonesian Citizenship Education curriculum and practices.

This discourse of moralism, coupled with adultism (where teachers/parents are role models, figures of authority and decision makers, as discussed in previous subsection), might result in paternalistic relationships between youth and teachers/parents and-as our data analysis shows below-has become a source of mental health problems in itself. A visual representation of this paternalism can be seen in the Year 7 Citizenship Education textbook (2017, p. 39) where a customary practice of students bowing down and kissing the hand of adults after a handshake is given as an example of 'a polite behaviour towards teachers'. Such degree of respect for authorities, within a context of moralism and piety, severely limits forms of youth-adult relationship, which are democratic and less hierarchical. As a result, adults' abuse of power and youth's lacking sense of agency can affect students' mental health. This is an insight developed by students taking part in this research: when asked what changes they wished for to improve their mental health, they referred to 'teachers who are not harsh to us', 'teachers who are less grumpy/angry in the class', 'no pop quizzes please' (Year 7 students' FGD), 'parents who understand us not just forcing us to do things' and 'parents who are supportive when we made decisions for ourselves' (Year 9 students' FGD). Here, adult authorities are positioned as potential causes of mental health symptoms. Young people called instead for the need to reshape youth-adult relationships in order for them to fully recognize - and engage with-young people's agency and identities. While democratic and supportive teachers/parents do exist, they are considered a luxury, not the default: 'I'm lucky because, unlike most parents, my parents are very supportive, like listening to my opinions and letting me make decisions for myself' (Jessica, Year 9). As previous studies have empirically demonstrated, more democratic approaches in adult-youth relationships tend to result in better mental health for youth (e.g. Nguyen, 2008; Yuwen \& Chen, 2013). Similarly, some studies documented that members of conservative religious communities that emphasised obedience, observance and piety reported poorer mental health (Mannheimer \& Hill, 2015; Nica, 2019). A discourse of moralism in the constitution of young Indonesian citizens-legitimated through religion and enforced through paternalistic relationship_considerably curtails the possibility of a democratic playing field between youth and teacher/parents where youth can be listened to, make decisions for themselves and flourish.

\section{CONCLUSION}

This article discussed three dominant discourses underpinning the ideal(ised) constructions of a young Indonesian citizen - namely neoliberalism, patriotism and moralism-which have characterised Citizenship Education in contemporary Indonesia. We argued that the discourse of mental health contradicted various aspects of these dominant discourses, from putting aside one's happiness in the face of patriotic calls for individual sacrifice and academic achievement, enduring high school work 
demands for the sake of one's own future in the labour market, to moralistic demands to obey and conform to social norms at the expense of one's sense of agency. We contend that understanding and improving youth mental health cannot be separated from socio-educational dynamics of youth citizenship in a particular geopolitico-historical context. By offering this discursive analysis, we contributed to the existing, largely depoliticised scholarship by connecting the field of mental health, Citizenship Education and the wider social contexts of contemporary Indonesia.

The implication of this analysis for youth mental health promotion is threefold. Firstly, it might be useful for youth mental health promotions to expand their currently dominant positivist, individualistic-level approaches to more contextual, socio-culturally relevant ones. This can be done by at least considering, in Indonesia, religious-cultural-educational contexts within which youth mental health problems exist. Drawing upon such a wider and multi-level understanding of mental health might generate new insights for more contextual, tailored and, therefore, effective alternative approaches in both prevention and intervention of mental health conditions. Secondly, mental health studies might find benefit in (re)politicising the commonly de-politicised analyses. As we demonstrated in this article, a youth's mental health conditions cannot be divorced from their ideological, political and historical backdrop. To transform a patient or a client into an activist fighting against injustices underpinning their mental health problem, for example, might be therapeutically liberating. Thirdly, as each context has its own conditions impeding youth mental health, it is equally important to explore contextual discursive resources that are available to improve youth mental health. In our study, there were glimpses of such resources, such as the promising new Minister of Education who, besides eliminating the high-stake national examination, reduced the imperative role of school accreditation and democratised teachers' and schools' autonomy. Although not using the term mental health per se, many teachers in our workshop have gained students' trust or at least known students' personal condition and expressed a genuine willingness to help them to flourish. The term 'caring', for example, occurred many times in their group discussions. Among the students, we identified a strong sense of youth sociality serving as social fabric, in which friendship becomes the space to share personal problems, to 'survive' schooling and to laugh together. Further identification and utilisation of such contextual resources may be beneficial for the development of mental health promotions, which are more effective, holistic and politically informed.

\section{CONFLICT OF INTEREST}

No potential conflict of interest was reported by the authors.

\section{ETHICAL APPROVAL}

The study was approved by the University of Surabaya Ethics Committee (approval no. 106/ $\mathrm{KE} / \mathrm{X} / 2019)$.

\section{DATA AVAILABILITY STATEMENT}

Research data (qualitative) are not shared to protect the confidentiality of participants' identity.

\section{ORCID}

Teguh Wijaya Mulya (D) https://orcid.org/0000-0002-8899-1157

Francesca Salvi (D) https://orcid.org/0000-0003-0545-643X

Paul Gorczynski (D) https://orcid.org/0000-0001-8876-8935

Tanya Wells Brown (D) https://orcid.org/0000-0002-0061-4518 


\section{REFERENCES}

Atterbury, K., \& Rowe, M. (2017). Citizenship, community mental health, and the common good: Citizenship, community mental health, and the common good. Behavioral Sciences \& the Law, 35(4), 273-287. https://doi. org/10.1002/bsl.2293

Bhatti, O. K., Alkahtani, A., Hassan, A., \& Sulaiman, M. (2015). The relationship between Islamic piety (taqwa) and workplace deviance with organizational justice as a moderator. International Journal of Business and Management, 10(4), 136-154. https://doi.org/10.5539/ijbm.v10n4p136

Bona, M. F. (2015, January 5). UN masih jadi momok bagi siswa. Berita Satu. Retrieved from https://www.beritasatu. com/paulus-c-nitbani/archive/238211/un-masih-jadi-momok-bagi-siswa.

Burford, J., \& Wijaya Mulya, T. (2019). Neoliberalism in Thai and Indonesian universities: Using photo-elicitation methods to picture space for possibility. In C. Manathunga \& D. Bottrell (Eds.), Resisting neoliberalism in higher education (Vol. II, pp. 219-245). Springer International Publishing. https://doi.org/10.1007/978-3-319-95834 $-7+11$

Connell, R. (2013). The neoliberal cascade and education: An essay on the market agenda and its consequences. Critical Studies in Education, 54(2), 99-112. https://doi.org/10.1080/17508487.2013.776990

Crabtree, S. A., \& Chong, G. (2000). Mental health and citizenship in Malaysia. International Social Work, 43(2), 217226. https://doi.org/10.1177/002087280004300207

Ecks, S. (2005). Pharmaceutical citizenship: Antidepressant marketing and the promise of demarginalization in India. Anthropology \& Medicine, 12(3), 239-254. https://doi.org/10.1080/13648470500291360

Education Law of Indonesia [Undang-undang Republik Indonesia nomor 20 tahun 2003 tentang sistem pendidikan nasional]. (2003). Retrieved from http://simkeu.kemdikbud.go.id/index.php/peraturan1/8-uu-undang-undang/12uu-no-20-tahun-2003-tentang-sistem-pendidikan-nasional

Ekornes, S. (2017). Teacher stress related to student mental health promotion: The match between perceived demands and competence to help students with mental health problems. Scandinavian Journal of Educational Research, 61(3), 333-353. https://doi.org/10.1080/00313831.2016.1147068

Foucault, M. (1972). The archaeology of knowledge and the discourse on language (A. M. S. Smith, Trans.). Pantheon Books.

Foucault, M. (1979). Discipline and punish: The birth of the prison (A. Sheridan, Trans.). Vintage Books.

Giota, J., \& Gustafsson, J.-E. (2017). Perceived demands of schooling, stress and mental health: Changes from grade 6 to grade 9 as a function of gender and cognitive ability: Stress and depression in adolescence. Stress and Health, 33(3), 253-266. https://doi.org/10.1002/smi.2693

Harris, N. (2004). Students, mental health and citizenship. Legal Studies, 24(3), 349-385. https://doi.org/10.1111/ j.1748-121X.2004.tb00254.x

Högberg, B., Lindgren, J., Johansson, K., Strandh, M., \& Petersen, S. (2021). Consequences of school grading systems on adolescent health: Evidence from a Swedish school reform. Journal of Education Policy, 36(1), 84-106. https:// doi.org/10.1080/02680939.2019.1686540

Högberg, B., Strandh, M., \& Hagquist, C. (2020). Gender and secular trends in adolescent mental health over 24 years: The role of school-related stress. Social Science \& Medicine, 250. https://doi.org/10.1016/j.socscimed.2020.112890

Hoon, C.-Y. (2013). Multicultural citizenship education in Indonesia: The case of a Chinese Christian school. Journal of Southeast Asian Studies, 44(3), 490-510. https://doi.org/10.1017/S0022463413000349

Intan, B. F. (2006). "Public Religion” and the Pancasila-based state of Indonesia: An ethical and sociological analysis. Peter Lang.

Irmansyah, I., Prasetyo, Y., \& Minas, H. (2009). Human rights of persons with mental illness in Indonesia: More than legislation is needed. International Journal of Mental Health Systems, 3(1), 14. https://doi.org/10.1186/1752-4458-3-14

Jackson, E., \& Bahrissalim. (2007). Crafting a new democracy: Civic education in Indonesian Islamic universities. Asia Pacific Journal of Education, 27(1), 41-54. https://doi.org/10.1080/02188790601142892

Junior High School counseling guidebook [Panduan operasional penyelenggaraan bimbingan dan konseling SMP]. (2016). Ministry of Education and Culture.

Kelly, B. D. (2009). Health services, psychiatry and citizenship in a globalizing world: A perspective from Ireland. Health Policy, 93(1), 48-54. https://doi.org/10.1016/j.healthpol.2009.06.001

Mannheimer, A. H., \& Hill, T. D. (2015). Deviating from religious norms and the mental health of conservative Protestants. Journal of Religion and Health, 54(5), 1826-1838. https://doi.org/10.1007/s10943-014-9951-y 
Mappiasse, S. (2014). Education reform in Indonesia: Limits of neoliberalism in a weak state (Doctor of Philosophy). University of Hawaii.

McCabe, K., Summerton, R., \& Parr, H. (2007). Mental health via cultural citizenship. Journal of Public Mental Health, 6(4), 33-36. https://doi.org/10.1108/17465729200700026

Morrow, M. (2004). Mental health reform, economic globalization and the practice of citizenship. Canadian Journal of Community Mental Health, 23(2), 39-50. https://doi.org/10.7870/cjcmh-2004-0012

Nguyen, P. V. (2008). Perceptions of Vietnamese fathers' acculturation levels, parenting styles, and mental health outcomes in Vietnamese American adolescent immigrants. Social Work, 53(4), 337-346. https://doi.org/10.1093/ sw/53.4.337

Nica, A. (2019). Exiters of religious fundamentalism: Reconstruction of social support and relationships related to well-being. Mental Health, Religion \& Culture, 22(5), 543-556. https://doi.org/10.1080/13674676.2019.1636015

Nilan, P. (2009). Contemporary masculinities and young men in Indonesia. Indonesia and the Malay World, 37(109), 327-344. https://doi.org/10.1080/13639810903269318

Parker, L., \& Hoon, C.-Y. (2013). Secularity, religion and the possibilities for religious citizenship. Asian Journal of Social Science, 41(2), 150-174. https://doi.org/10.1163/15685314-12341296

Pelletier, J.-F., Davidson, L., \& Roelandt, J.-L. (2009). Citizenship and recovery for everyone: A global model of public mental health. International Journal of Mental Health Promotion, 11(4), 45-53. https://doi.org/10.1080/14623 730.2009 .9721799

Pols, J. (2016). Analyzing social spaces: Relational citizenship for patients leaving mental health care institutions. Medical Anthropology, 35(2), 177-192. https://doi.org/10.1080/01459740.2015.1101101

Prior, P. (2007). Citizenship and mental health policy in Europe. Social Work \& Society, 5(3), 115-124.

Robinson, K. (2014). Citizenship, identity and difference in Indonesia. Review of Indonesian and Malaysian Affairs, 48(1), 5-34. Retrieved from https://search.informit.org/doi/10.3316/informit.893852080367316

Shihab, N. (2019, December 18). Menguji ujian nasional: Curhatan anak SMA soal ujian nasional (Part 1)|Mata Najwa [Video]. Youtube. Retrieved from https://www.youtube.com/watch?v=e4J8pgQ4woE

Sung, M. (2010). The psychiatric power of neo-liberal citizenship: The North Korean human rights crisis, North Korean settlers, and incompetent citizens. Citizenship Studies, 14(2), 127-144. https://doi.org/10.1080/1362102100 3594783

Torrance, H. (2017). Blaming the victim: Assessment, examinations, and the responsibilisation of students and teachers in neo-liberal governance. Discourse: Studies in the Cultural Politics of Education, 38(1), 83-96. https://doi. org/10.1080/01596306.2015.1104854

Ubaedillah, A. (2018). Civic education for Muslim students in the era of democracy: Lessons learned from Indonesia. The Review of Faith \& International Affairs, 16(2), 50-61. https://doi.org/10.1080/15570274.2018.1469837

Uly, Y. A. (2019, December 11). Kenapa UN dihapus? Nadiem: Jadi beban stres murid dan orangtua. Okenews. Retrieved from https://news.okezone.com/read/2019/12/11/65/2140747/kenapa-un-dihapus-nadiem-jadi-beban -stres-murid-dan-orangtua

WHO. (2018, March 30). Mental health: Strengthening our response. Retrieved from https://www.who.int/news-room/ fact-sheets/detail/mental-health-strengthening-our-response.

Wijaya Mulya, T. (2016). Neoliberalism within psychology higher education in Indonesia: A critical analysis. Anima Indonesian Psychological Journal, 32(1), 1-11. Retrieved from http://anima.ubaya.ac.id/index.php?menu=artic les\&eid $=1503219745 \&$ actsub $=$ yes\&eidsub $=1503219821$

Willig, C. (2013). Introducing qualitative research in psychology. Open University Press.

Willis, A., Hyde, M., \& Black, A. (2019). Juggling with both hands tied behind my back: Teachers' views and experiences of the tensions between student well-being concerns and academic performance improvement agendas. American Educational Research Journal, 56(6), 2644-2673. https://doi.org/10.3102/0002831219849877

Woolford, A., \& Nelund, A. (2013). The responsibilities of the poor: Performing neoliberal citizenship within the bureaucratic field. Social Service Review, 87(2), 292-318. https://doi.org/10.1086/671072

Yang, R., You, X., Zhang, Y., Lian, L., \& Feng, W. (2019). Teachers' mental health becoming worse: The case of China. International Journal of Educational Development, 70, https://doi.org/10.1016/j.ijedudev.2019.102077.

Year 7 student Citizenship Education textbook [Pendidikan Pancasila dan kewarganegaraan kelas VII]. (2017). Ministry of Education and Culture.

Year 8 Citizenship Education teacher guidebook. (2017). Ministry of Education and Culture. 
Year 9 Student Citizenship Education Textbook [Pendidikan Pancasila dan kewarganegaraan kelas IX]. (2017). Ministry of Education and Culture.

Yuwen, W., \& Chen, A. C. C. (2013). Chinese American adolescents: Perceived parenting styles and adolescents' psychosocial health: Chinese American adolescents. International Nursing Review, 60(2), 236-243. https://doi. org/10.1111/inr.12002

Yuwono, M. (2019, December 13). Ditanya soal Penghapusan UN, Jusuf Kalla: Jangan Jadi Generasi Muda yang Lembek. Kompas. Retrieved from https://regional.kompas.com/read/2019/12/13/13045841/ditanya-soal-pengh apusan-un-jusuf-kalla-jangan-jadi-generasi-muda-yang.

\section{AUTHOR BIOGRAPHIES}

Teguh Wijaya Mulya is a lecturer in the Faculty of Psychology at the University of Surabaya, Indonesia. He specialises in critical research in the areas of sexuality, gender, religion, youth and neoliberalism in education. His work is inspired by the work of Michel Foucault, post-structuralist feminism and discourse theories.

Francesca Salvi is a sociologist of education focusing on transitions between childhood and adulthood. Her research looks at how global discourses construct teenage as deficit within the opposition of education and parenthood. More recently, she has started to consider the disconnect between global and local discourses of mental health in relation to young people in Indonesia.

Paul Gorczynski is a chartered psychologist and associate fellow of the British Psychological Society. He specialises in mental health promotion in clinical, educational and elite sport settings. Paul has helped write consensus and expert statements on mental health for the International Olympic Committee and The British Association of Sport and Exercise Sciences.

Tanya Wells Brown is a public health specialist and Dr. Public Health Candidate at the London School of Hygiene and Tropical Medicine. She specialises in gender-based violence, in particular the integration of GBV protocols within health systems, and adolescent sexual and reproductive health. She consults with UN Agencies and the US Agency for International Development.

How to cite this article: Wijaya Mulya, T., Salvi, F., Gorczynski, P., \& Wells Brown, T.... Wells Brown, T. (2021). The state and my happiness: Youth mental health, citizenship education and discursive contestations in contemporary Indonesia. Children \& Society, 00, e12481. https://doi.org/10.1111/chso.12481 